\title{
Assessment of Technology Gap and Productivity Gain through Improved Technology Demonstration in Chickpea
}

\author{
Jatav Sunil Kumar", B.K. Prajapati, R.P. Ahirwar, R.L. Raut and S.R. Duware
}

Krishi Vigyan Kendra, Balaghat, Madhya Pradesh, India

*Corresponding author

\section{A B S T R A C T}

\section{Keywords \\ Chickpea, Variety, Improved technology, Gap analysis, Grain yield, Productivity \\ Article Info \\ Accepted: \\ 20 August 2018 \\ Available Online: \\ 10 September 2018}

This study was undertaken in Krishi Vigyan Kendra, Balagaht (M.P.) during the period from 2014-15 to 2017-18 conducted a total 48 frontline demonstration of Chickpea crop. Cultivation practices comprised under FLD viz. use of improve variety (JG -14, JG-130), seed treatment, seed inoculation, spacing $30 \mathrm{~cm}$, soil test based nutrient management, irrigation water management and integrated pest management show that percentage increase in the yield of Chick pea ranged from $22.73 \%$ to $46.11 \%$ over farmer's practice. The highest seed yield $16.80 \mathrm{q} \mathrm{ha}^{-1}$ was recorded in the year 2016-17 in FLD, which was $22.73 \%$ more over the farmer's practice ( $\left.13.20 \mathrm{q} \mathrm{ha}^{-1}\right)$. The additional cost Rs. 2650 to Rs. 3740 gave additional net return, it was ranged from Rs. 9460 to Rs. 14544 per hectare. The increased benefit: Cost ratio was also calculated, it was ranged from 1:2.46 to 1:3.41 in demonstration \&1:2.11 to $1: 3.38$ in farmers practice.

\section{Introduction}

Chickpea (Cicer arietinum L.) is the premier pulse crop of India. India is the largest producer of chickpea accounting to 75 per cent of world production. Madhya Pradesh shares 36 per cent of the country's area under chickpea. However, the average productivity in the state is low $(1105 \mathrm{~kg} / \mathrm{ha})$. This is not because of the unavailability of improved varieties but lack of adoption of improved production technologies. India produces 98.80 lakh ton chickpea in area of 99.27 lakh ha. and given average productivity $995 \mathrm{~kg} / \mathrm{ha}$. Madhya Pradesh produces 17.30 lakh ton chickpea in area of 34.46 lakh ha. and district Balaghat produce 58.86 tons chickpea in area of 41.10 ha. and given average productivity $1432 \mathrm{~kg} / \mathrm{ha}$ (http://mpkrishi.mp.gov.in, 2016-17). The frontline demonstration programme (FLD's) in pulses is a noble initiative by Ministry of Agriculture, Govt. of India, which is conducted under close supervision of the scientists.

The main objective of FLD's in pulses is to demonstrate and popularize the improved agro-technology on farmers' fields under varied existing farming situations for effective transfer of generated technology and fill the gap between improved technology and adopted/ indigenous technology to enhance the pulse productivity and farm gains through pulses intensification and diversification for sustaining the production systems. Keeping in view the importance of pulses in food security 
and being vital component of our farming systems, KVKs to bring in enhanced application of modern technologies to generate yield data and collection of farmer's feedback. Keeping this in view, front line demonstrations of chickpea were conducted, to exhibit the performance of recognized and recommended high yielding chickpea varieties with Full recommended package of practices for harvesting higher crop yields and compare the yield levels of local check (farmers' field) and FLD fields.

\section{Materials and Methods}

The present study was carried out by the Krishi Vigyan Kendra, Balaghat (M.P.) during Rabi season from the year 2014-15, 2015-16, 2016-17 and 2017-18 in farmer's field of 5 adopted villages viz. Amlajeeri, Badgaon, Bagdmara, Kosate and Amgaon. The total number of farmers under this programme was 48. The total area in 4 years was 20 hectare for demonstration of recommended improve practices of Chick pea. Data were collected with the help of personal contact and observations on yield data was also recorded at the time of separate threshing. The yield of each demonstration was recorded in appropriate manner and the yield of farmer's practices was also recorded at the same time.

The results on farmers practice were compared with recommended practice (Improved variety JG - 14, JG-130) under demonstrations. Package of practices as developed for the region were strictly followed. Recommended seed rate i.e. $75 \mathrm{~kg} / \mathrm{ha}$ against existing farmers practice of using $100 \mathrm{~kg} / \mathrm{ha}$ (local check) was broadcasting method The seeds were treated with Trichodermaor carboxin + thiram, then seeds were inoculated by Rhizobium and Phospho-solubilizing bacteria biofertilizers each $100 \mathrm{ml}$ or $200 \mathrm{~g} / 30 \mathrm{Kg}$ seeds. The Pheromone trap @ $10 \mathrm{No} / \mathrm{ha}$ and bird purchers @ $50 \mathrm{No} / \mathrm{ha}$ were fixed after 20 days of sowing. As per soil test value, nutrients i.e. N.P.K in the ratio of 20: 60: $20 \mathrm{~kg} / \mathrm{ha}$ applied through DAP, MOP and urea. Total amount of $\mathrm{P}$ and $\mathrm{S}$ and half of $\mathrm{N}$ was applied as basal dose and the remaining $50 \%$ of $\mathrm{N}$ was top dressed in two equal splits at 30 and 45 days after sowing. In control group (local check) farmers were apply of DAP fertilizers in chickpea crop. Technological gap, extension gap and technology index were calculated using following equations Kumar R (2014).

Technology gap = Potential yielddemonstration yield

Extension gap $=$ Demonstration yield farmer's yield

Technology index $=\frac{(\text { Potential yield }- \text { Demonstration yield })}{\text { Potential yield }} \times 100$

Effective gain $=$ Additional return - Additional cost

Additional return $=$ Dem. return - Farmers practice return

Incremental B: C ratio $=\frac{\text { Gross Return }}{\text { Gross Cost }}$

\section{Results and Discussion}

The findings of the present study as well as relevant discussion have been presented as under:

Total 48 frontline demonstrations were conducted at farmer's field in their farming situation. Indicated the factor considered for selection of critical input under FLD. There was partial gap in adoption of recommended practices over farmer's practices with regards to improved varieties, seed rate, fertilizers and plant protection measures. Whereas completed gap was renowned for variety, seed treatment, seed inoculation and spacing (Table 1). 
Table.1 Adoption gap of recommended chick pea production technology and percentage of farmers of non-adoption recommended practices

\begin{tabular}{|c|c|c|c|c|c|c|}
\hline S.N. & Items & Existing practices & Recommended practices & $\begin{array}{l}\text { Gap in } \\
\text { adoption }\end{array}$ & $\begin{array}{l}\% \text { of } \\
\text { farmers }\end{array}$ & $\begin{array}{l}\text { Farmers } \\
\text { prioritization for } \\
\text { critical input }\end{array}$ \\
\hline 1. & Variety & Old variety, Cheni & JG-130, JG-14 & Partial & 90 & II \\
\hline 2. & Seed rate & 100 Kg ha-1 & $75 \mathrm{Kg}$ ha-1 & Partial & 80 & $\mathrm{~V}$ \\
\hline 3. & Seed treatment & $\begin{array}{l}\text { No use of } \\
\text { fungicide }\end{array}$ & $\begin{array}{l}\text { Seed treatment with carboxin } \\
\text { + thiram@3 gm / } \\
\text { Trichoderma@ @ gm/ Kg } \\
\text { seed }\end{array}$ & Full & 85 & III \\
\hline 4. & $\begin{array}{l}\text { Seed } \\
\text { inoculation }\end{array}$ & No use of culture & $\begin{array}{l}\text { Seed inoculation with } \\
\text { Rhizobium \& PSB @ 200gm } \\
\text { or } 100 \mathrm{ml} \text { each for } 30 \mathrm{~kg} \\
\text { seed }\end{array}$ & Full & 85 & IV \\
\hline 5. & Spacing & $20 \mathrm{~cm}$ & $30 \mathrm{~cm}$ & Full & 90 & VIII \\
\hline 6. & Fertilizers & 50 kg DAP ha-1 & $\begin{array}{l}\text { 20:60:20 Kg ha-1 N:P:K (As } \\
\text { per STV) }\end{array}$ & Partial & 75 & I \\
\hline 7. & Irrigation & $\begin{array}{l}\text { One pre sown } \\
\text { \&one irrigation } \\
\text { before flowering }\end{array}$ & $\begin{array}{l}\text { One pre sown \& one } \\
\text { irrigation before flowering } \\
\text { second during pod formation }\end{array}$ & Partial & 80 & VI \\
\hline 8. & $\begin{array}{l}\text { Plant } \\
\text { Protection }\end{array}$ & $\begin{array}{l}\text { Improper use of } \\
\text { insecticide }\end{array}$ & $\begin{array}{l}\text { Application of IPM module } \\
\text {-Pheromone trap, Bird } \\
\text { purcher and Need based } \\
\text { application of insecticide }\end{array}$ & Partial & 90 & VII \\
\hline
\end{tabular}


Table.2 Grain yield and gap analysis of front line demonstrations on chickpea at farmer's field

\begin{tabular}{|c|c|c|c|c|c|c|c|c|c|c|}
\hline \multirow[t]{2}{*}{ Year } & \multirow{2}{*}{$\begin{array}{l}\text { Area } \\
\text { (ha) }\end{array}$} & \multirow{2}{*}{$\begin{array}{l}\text { No. of } \\
\text { Demo }\end{array}$} & \multirow{2}{*}{$\begin{array}{l}\text { Variety/ } \\
\text { Technology }\end{array}$} & \multirow{2}{*}{$\begin{array}{l}\text { Potential } \\
\text { Yield } \\
\text { (q/ha) }\end{array}$} & \multicolumn{2}{|c|}{ Yield q/ha } & \multirow{2}{*}{$\begin{array}{l}\% \\
\text { increase }\end{array}$} & \multirow{2}{*}{$\begin{array}{l}\text { Extension } \\
\text { gap q/ha }\end{array}$} & \multirow{2}{*}{$\begin{array}{l}\text { Technology } \\
\text { gap q/ha }\end{array}$} & \multirow{2}{*}{$\begin{array}{l}\text { Technology } \\
\text { index\% }\end{array}$} \\
\hline & & & & & Demo & FP & & & & \\
\hline 2014-15 & 5 & 12 & JG-14 & 19.00 & 14.96 & 10.36 & 44.40 & 4.60 & 4.04 & 21.26 \\
\hline $2015-16$ & 5 & 12 & JG-14 & 19.00 & 15.86 & 10.84 & 46.31 & 5.02 & 3.14 & 16.53 \\
\hline 2016-17 & 5 & 12 & JG-14 & 19.00 & 16.80 & 12.98 & 29.43 & 3.82 & 2.20 & 11.58 \\
\hline 2017-18 & 5 & 12 & JG-130 & 18.00 & 16.20 & 13.20 & 22.73 & 3.00 & 1.80 & 10.00 \\
\hline Total & 20 & 48 & - & - & - & - & - & - & - & - \\
\hline Mean & - & - & - & 18.75 & 15.96 & 11.85 & 35.72 & 4.11 & 2.80 & 14.84 \\
\hline
\end{tabular}

Table.3 Economic analysis of front line demonstrations on chickpea at farmer's field

\begin{tabular}{|c|c|c|c|c|c|c|c|c|c|c|c|}
\hline \multirow[t]{2}{*}{ Year } & \multicolumn{2}{|c|}{$\begin{array}{l}\text { Cost of } \\
\text { cultivation } \\
\text { (Rs/ha) }\end{array}$} & \multirow{2}{*}{$\begin{array}{l}\text { Additional } \\
\text { cost in } \\
\text { Demo } \\
\text { (Rs/ha) }\end{array}$} & \multicolumn{2}{|c|}{$\begin{array}{l}\text { Gross Return } \\
\text { (Rs/ha) }\end{array}$} & \multicolumn{2}{|c|}{$\begin{array}{l}\text { Average Net } \\
\text { Return (Rs/ha) }\end{array}$} & \multirow{2}{*}{$\begin{array}{l}\text { Additional } \\
\text { return in } \\
\text { Demo } \\
\text { (Rs/ha) }\end{array}$} & \multirow[t]{2}{*}{$\begin{array}{l}\text { Effective } \\
\text { gain } \\
\text { (Rs./ha) }\end{array}$} & \multicolumn{2}{|c|}{$\begin{array}{l}\text { Incremental } \\
\text { Benefit-Cost } \\
\text { Ratio }\end{array}$} \\
\hline & Demo & FP & & Demo & FP & Demo & FP & & & Demo & FP \\
\hline 2014-15 & 19300 & 15620 & 3680 & 47498 & 32893 & 28198 & 17273 & 10925 & 7245 & 2.46 & 2.11 \\
\hline $2015-16$ & 19050 & 16400 & 2650 & 54321 & 37127 & 35271 & 20727 & 14544 & 11894 & 2.85 & 2.26 \\
\hline 2016-17 & 20250 & 17570 & 2680 & 58800 & 45430 & 38550 & 27860 & 10690 & 8010 & 2.90 & 2.59 \\
\hline 2017-18 & 20900 & 17160 & 3740 & 71280 & 58080 & 50380 & 40920 & 9460 & 5720 & 3.41 & 3.38 \\
\hline Mean & 19875 & 16688 & 3188 & 57975 & 43383 & 38100 & 26695 & 11405 & 8217 & 2.91 & 2.58 \\
\hline
\end{tabular}




\section{Grain yield}

The increase in grain yield under demonstration was 22.73 to 46.11 per cent than farmers 'local practices. On the basis of four years, 35.72 per cent yield advantage was recorded under demonstrations carried out with improved cultivation technology as compared to farmers' traditional way of chickpea cultivation (Table 2).

\section{Gap analysis}

An extension gap of $3.00-5.02$ quintal per hectare was found between demonstrated technology and farmers practices during different four years and on average basis the extension gap was 4.11 quintal per hectare (Table 2). The extension gap was lowest (3 q/ha) during 2017-18 and was highest (5.02 q/ha) during 2015-16. Such gap might be attributed to adoption of improved technology in demonstrations which resulted in higher grain yield than the traditional farmer's practices. Wide technology gap were observed during different years and this was lowest (1.08 q/ha) during 2017-18 and was highest (4.04 kg/ha) during 2014-15. On four years average basis the technology gap of total 48 demonstrations was found as 2.80 quintal per hectare.

The difference in technology gap during different years could be due to more feasibility of recommended technologies during different years. Similarly, the technology index for all the demonstrations during different years were in accordance with technology gap. Higher technology index reflected the inadequate proven technology for transferring to farmers and insufficient extension services for transfer of technology. Technology index was lowest $(10.00 \%)$ during 2017-18 and was highest (21.26\%) during 2014-15. On four years average basis the Technology of total 48 demonstrations was found as 14.84 per cent. Similar findings were also found by Singh $e t$ al., (2013) and Kumar et al., (2016).

\section{Economic analysis}

Different variables like variety, seed, fertilizers, bio fertilizers and pesticides were considered as cash inputs for the demonstrations as well as farmers practice and on an average an additional investment of Rs. 3188 per ha was made under demonstrations. Economic returns as a function of grain yield and MSP sale price varied during different years. Demonstration maximum returns (Rs. 50380 per ha) during the year 2017-18 was obtained due to higher grain yield. The higher additional returns and effective gain obtained under demonstrations could be due to improved technology, nonmonetary factors, timely operations of crop cultivation and scientific monitoring. The lowest and highest incremental benefit: cost ratio was (2.46 and 3.41 in 2014-15 and 201718 , respectively (Table 3 ) depends on produced grain yield and MSP sale rates. Overall average IBCR was found as 2.91, while incremental benefit: A cost ratio farmer practice was found as 2.58 . The similar results founding in front line demonstrations on Chickpea crop by Tomar (2010).

These technologies were found to be the main reason for increase in the yield of chickpea and thus it can be said that FLDs were the most successful tools for transfer of technology. The concept of front line demonstration may be applied to all farmer categories including progressive farmers for speedy and wider dissemination of the recommended practices to other members of the farming community so the front line demonstration (FLDs) plays a very important role to disseminate recommended technologies because it shows the potential of technologies resulting in an increase in yield 
at farmers' level. Under demonstrations some specific technologies like, improved varieties, seed treatment, seed rate, balance use of fertilizer, intercultural and plant protection measures were undertaken in a proper way the demonstration farmers acted also as primary source of information on the improved practices of chickpea cultivation and also replaced as source of good quality pure seeds in their locality and surrounding area for the next crop.

\section{References}

Kumar U., Sahu A. K., Chouhan S. And Kantwa S. C. 2016. Enhancement of chickpea productivity through improved technology in farming community. International Journal of Agriculture Sciences, 8(53):2755-2757.

Kumar, R., 2014. Assessment of technology gap and productivity gain through crop technology demonstration in chickpea. Indian J. Agric. Res., 48: (2) 162-164.

Meena, M. L. 2017. Effect of Front Line Demonstrations of Chickpea Cv. RSG888 on Farmers' Field in Rainfed Condition of Rajasthan, India, Asian Journal of Agricultural Extension, Economics \& Sociology, 18(2): 1-7.

Singh, H.P., Gupta, R., Shaktawat, R.P.S. and Singh, D. 2013. Boosting chickpea production through front line demonstrations in KVK operational area district Mandsaur Madhya Pradesh. International Journal of Plant Protection, 2(6):361-363

Tomar, R.K.S. 2010. Maximization of productivity for chickpea (Cicer arietinum L.) through improved technologies in farmer's fields. Indian J. Natural Products \& Resources, 1(4): 515-517.

\section{How to cite this article:}

Jatav Sunil Kumar, B.K. Prajapati, R.P. Ahirwar, R.L. Raut and Duware, S.R. 2018. Assessment of Technology Gap and Productivity Gain through Improved Technology Demonstration in Chickpea. Int.J.Curr.Microbiol.App.Sci. 7(09): 2971-2976. doi: https://doi.org/10.20546/ijcmas.2018.709.369 